\title{
UGOVOR O OSIGURANJU SPORTAŠA OD POSLJEDICA NESRETNOG SLUČAJA
}

\author{
UDK: 796/: 368. 91 \\ Primljeno: 20. 01. 2019. \\ Pregledni znanstveni rad
}

\begin{abstract}
Obavljanje sportske djelatnosti nosi sa sobom signifikantne rizike u vidu narušenja zdravlja i posljedičnih imovinskih gubitaka, iz čega je proizišla potreba interpolacije instituta ugovornog osiguranja u odnosu na tako uzrokovane štetne posljedice. Pravni model koji omogućuje učinkovitu zaštitu imovinskih interesa sportaša kao potencijalnih oštećenika jest upravo ugovor o osiguranju sportaša od posljedica nesretnog slučaja, koji je odabran kao središnje istraživačko pitanje ovog rada. Odgovarajućom primjenom znanstvenih metoda utvrđen je relevantan građanskopravni okvir za pružanje osigurateljne pravne zaštite od sportskih ozljeda unutar hrvatskog pozitivnog prava s osvrtom na posebnu pretpostavku zaključenja tipičnog ugovora o osiguranju - postojanje osigurljivog rizika, kao pravnog i faktičnog pitanja sui generis.
\end{abstract}

Ključne riječi: sportsko osiguranje, ugovor o osiguranju sportaša od posljedica nesretnog slučaja, osigurani slučaj, osigurani rizik, nesretni slučaj, sportska tjelesna ozljeda, pravo osiguranja, građansko pravo

\section{UVOD}

\subsection{Fenomenologija osiguranja od sportskih ozljeda}

Već rane europske civilizacije u bavljenju sportom prepoznavale su jedan od načina promocije zdravlja koji pri tome stvara izvjesnu životnu radost kako sudionicima, tako i promatračima. Pored toga sport je djelotvoran instrument promicanja socijalnih vještina te nerijetko i značajan element koji izgrađuje društvenu koheziju kolektiviteta od razine manjih grupa do nacije. Po svom pozitivno romantičarskom tonalitetu izdvaja se uvjerenje da sudjelovanje u sportskom natjecanju može izgrađivati čvrst karakter, razvijati sposobnost zdravog rasuđivanja i poticati na pošteno ponašanje. $U$ tom smislu je iskovana primjerena sintagma o "religiji sporta" koja može naučiti ljude da žive u miru. ${ }^{1} \mathrm{~S}$ vremenom je profesionalni sport postao iznimno profitabilna djelatnost i donekle se udaljio od svojih plemenitih ideala na koje se u svoje doba pozivao barun Pierre de Coubertin kad je predložio obnavljanje Olimpijskih igara. Čuveni moto suvremenog sporta: “(...) Nije najvažnije pobijediti, važno je sudjelovati. (...) Nije glavno biti pobjednik,

\footnotetext{
1 Barun Pierre De Coubertin.
} 
važno je dobro se boriti.", kao da je pao u drugi plan pod utjecajem financijske moći globalne sportske industrije. Indikativan je podatak kako je industrija sporta dosegla razinu od čak 3\% ukupne svjetske trgovine sa pripadajućim udjelom od 2\% BDP za 25 zemalja Europske Unije. ${ }^{2}$

U isto vrijeme za sport se kaže da u svim svojim varijantama predstavlja opasnost koja radost djelovanja ponekad pretvara u tugu mirovanja. ${ }^{3}$ Iznesenu tvrdnju dobro ilustrira činjenica da je u godini dana čak 3,1\% odraslih Nijemaca pretrpilo neku vrstu sportske ozljede, a što promatrano kroz prizmu statistike navedeni rizik svrstava na visoko drugo mjesto uobičajenih nezgoda i to odmah nakon tzv. kućnih nezgoda $(3,7 \%)$, a prije prometnih nezgoda $(1,8 \%) .{ }^{4}$ Upozorava se da sport karakterizira raznolikost i velik broj subjekata na istom prostoru u isto vrijeme koji su pod utjecajem strasti natjecanja, pri čemu se razvija maksimalna fizička energija. ${ }^{5}$ Bez obzira da li je u pitanju rekreativni ili profesionalni sport tako oslobođenu fizičku energiju nije lako kontrolirati, a što zahtijeva krajnju opreznost i poštovanje sportske discipline uzevši u obzir realne rizike od sportskih šteta kako za natjecatelje, tako i za treće osobe. ${ }^{6}$ Neprijeporno je da obavljanje sportske djelatnosti nosi sa sobom signifikantne rizike u vidu narušenja zdravlja i posljedičnih imovinskih gubitaka iz čega je proizišla potreba interpolacije instituta ugovornog osiguranja tako nastalih šteta i to u pogledu svih standardnih vrsta osiguranja. Na financijski volumen šteta dobro ukazuje podatak kojeg iznose američki osiguratelji, a prema kojem kumulativni trošak od sportskih ozljeda doseže iznos od vrtoglavih bilijun \$ na godišnjoj razini! ${ }^{7}$ Dakle, ultima ratio osiguranja od sportskih ozljeda predstavljen je u ideji popravljanja, odnosno, sanacije i umanjenja svih onih nepovoljnih financijskih učinaka koji su rezultanta ostvarenog rizika za vrijeme prakticiranja određene sportske aktivnosti. Pravni model koji omogućuje djelotvornu pravno-ekonomsku zaštitu sportaša kao potencijalnih oštećenika jest upravo ugovor o osiguranju sportaša od posljedica nesretnog slučaja koji je odabran kao središnje istraživačko pitanje ovog rada.

U ostvarenju cilja ovog rada istraženi su bitni elementi predmetnog ugovora i to na osnovi ugovornog obrasca (opći i dopunski uvjeti) kojeg nudi vodeći osiguratelj na hrvatskom tržištu osiguranja. Usporedno je da sumarni prikaz karakterističnih elemenata nekih drugih ugovora o osiguranju koji se odnose na istovjetne osigurane rizike, a koji se na domaćem tržištu nalaze u ponudi drugih osiguravajućih kuća

2 Blackshow, I., The professional athlete-employee or enterpreneur?, The International Sports Law Journal, July-Oct, 2006., str. 1.

3 Ćurković, M., Hrvatski sportaši osigurani samo sponzorskim ugovorima, Svijet osiguranja, br. 1, 2007., str. 24.

4 Schneider, S. et al., Sports injuries: population based representative data on incidence, diagnosis, sequelae, and high risk groups, vol. 40, no. 4, https://www.ncbi.nlm.nih.gov/pmc/articles/PMC2586164/, 1. IX. 2018.

5 Losco, G., La responsabilite civile, 2 izdanje, Giuffre, Milano, 1997., str. 87.

6 Ćurković, M., Mnogo rizika, malo osiguranja, Svijet osiguranja, br. 2, 2007., str. 50.

http://www.injuryfree.org/safetytpc_display.cfm?PermanentId=75C650E2-2718-41AB-

B1BC0504AB625450, prema Proso, M., Sportsko osiguranje, Zbornik radova Pravnog fakulteta u Splitu, god. 47, br. 2, 2010., str. 416. 
ili posrednika u osiguranju. Znanstvenoistraživačke metode primijenjene u ovome znanstvenom radu jesu komparativna i induktivna metoda. Odgovarajućom primjenom znanstvenih metoda utvrđen je relevantan građanskopravni okvir za pružanje osigurateljne pravne zaštite od sportskih ozljeda unutar hrvatskog pozitivnog prava. Rad je strukturiran na način da je uvodno analiziran širi pravni i socio-ekonomski kontekst osiguranja sportaša od nesretnog slučaja, te je nastavno prikazan tipičan i prevladavajući oblik ugovora o osiguranju sa posebnim osvrtom na pravni odnos koji nastaje između subjekata odnosnog ugovora. U tom smislu istraženi su, inter alia, prava i dužnosti ugovornih strana i korisnika osiguranja; opseg osigurateljnog pokrića kao i razlozi isključenja obveze osiguratelja na isplatu osigurnine; razgraničenje i definicija relevantnih pojmova - osigurani slučaj / rizik / nesretni slučaj; te postupak prijave, utvrđenja i isplate osigurane svote.

\subsection{Osiguranje od sportskih ozljeda na hrvatskom tržištu osiguranja}

Osiguranje sportaša od sportskih ozljeda u okviru hrvatskog osigurateljnog tržišta još uvijek nije steklo status važnije teme pa su konzekventno tome navedena osiguranja relativno rijetka u našoj praksi. Istodobno ponuđeni uvjeti osiguranja međusobno su podudarni u bitnim elementima bez značajnijih odstupanja što svjedoči nezainteresiranosti osiguravajućih kuća da učine iskorak u smjeru veće tržišne kompetitivnosti. Razloga je svakako više, s jedne strane, nedovoljna organizacija ukupnog sustava sportskih djelatnosti, te s druge strane, permanentni deficit financijskih sredstava za daljnja ulaganja u sport, a što za prirodnu posljedicu ima nedostatnu razvijenost tržišta osiguranja u promatranom segmentu. Nije rijetkost da se zabilježe problemi sa naplatom premije tako da objektivno, na hrvatskom tržištu osiguranja, police osiguranja od sportskih ozljeda nisu posebno tražen osigurateljni proizvod. Dapače, vrlo je uobičajeno da se ugovor o osiguranju zaključi u režimu sponzorstva od strane osiguratelja pri čemu se, u pravilu, ugovara protučinidba u obliku marketinške promocije korporativnog identiteta tvrtke osiguratelja i slično. Na osnovi iznesenog se može izvesti zaključak kako praktična važnost osiguranja još uvijek nije dostatno prepoznata na hrvatskom tržištu, a kao ilustrativni primjer diskrepancije može se spomenuti slučaj bivšeg britanskog nogometaša Bena Colletta (Manchester United) koji je sudskim putem izborio pravo na naknadu štete u iznosu od cca. 4,5 milijuna funti na ime dvostrukog prijeloma noge od strane igrača suparničkog kluba. Pretrpljena tjelesna ozljeda je posljedično uzrokovala prekid inače uspješne nogometne karijere mladog sportaša. ${ }^{8}$

Osiguranje sportskih rizika u Hrvatskoj karakterizira nepostojanje specijaliziranih osiguratelja pa niti posebnih organizacijskih jedinica koje bi plasirale proizvode sportskih osiguranja. Također, na osnovi službenih podataka Hrvatskog ureda za osiguranje ${ }^{9}$ nije moguće jasno utvrditi iznos premije po osnovi

8 Ibid., str. 415.

9 Hrvatski ured za osiguranje, Tržište osiguranja u Republici Hrvatskoj 2017., kolovoz 2018., str. 42-44. 
ugovora o osiguranja sportaša od nesretnog slučaja. Naime, osiguranje od nezgode pripada skupini neživotnih osobnih osiguranja jer je rizik analogan ostalim riziko osiguranjima i vezan za određeni događaj tijekom trajanja osiguranja. ${ }^{10}$ Prema važećem podzakonskom aktu predmetno osiguranje sportaša pripada u prvu skupinu osiguranja od nezgode i vodi se pod šifrom - 01.02 - Osiguranje osoba od posljedica nezgode u motornim vozilima i pri posebnim djelatnostima ,koja obuhvaća više vrsta osiguranja od nezgode uključujući i sportaše. ${ }^{11}$ Zaračunata bruto premija na hrvatskom osigurateljnom tržištu za sva osiguranja od nezgode pod navedenom šifrom kumulativno iznosi 163.829.471 kn u 2017 godini. Treba naglasiti kako daljnja diferencijacija u cilju točnog utvrđenja zaračunate premije za osiguranje od nezgode sportaša nije moguća, uslijed ograničavajućih čimbenika oficijelne klasifikacije vrsta i skupina osiguranja, kao i nevoljkosti osiguratelja da predoče financijske podatke o poslovanju radi poslovne tajne.

Za razliku od Hrvatske u inozemstvu djeluje veći broj specijaliziranih osiguratelja koji su razvili lukrativan posao. Tako je, primjerice, u Śvedskoj 90\% svih sportaša osigurano kod istog specijaliziranog osiguratelja, te se na nacionalnoj razini redovno vodi baza podataka za sportske ozljede i provode mjere prevencije od "sportskih šteta". Ističe se da čak 18-30\% svih akutnih tjelesnih ozljeda ima svoj uzrok u sportskim aktivnostima, pri čemu pola od tih ozljeda otpada na timske sportove (nogomet, rukomet, košarka). ${ }^{12}$ Slična situacija je i u Njemačkoj gdje sportski savezi imaju zaključene okvirne ugovore za članove saveza. Za Veliku Britaniju se iznosi podatak od čak 20 milijuna sportskih ozljeda godišnje, a tamošnji profesionalni i amaterski sport je pokriven osigurateljnim policama više društava za osiguranje koji djeluju na tom iznimno razvijenom tržištu. Od osiguratelja se posebno ističe Lloydov sindikat 3334 Sportcover osnovan u Australiji 1986.g. koji je u razmjerno kratkom razdoblju uspio osigurati više od dva milijuna sportaša. ${ }^{13}$

\subsection{Obvezno ili dobrovoljno osiguranje od sportskih ozljeda}

Osiguranje sportaša od posljedica nesretnog slučaja nema u hrvatskom pravu karakter obveznog osiguranja već se temelji na načelu dobrovoljnosti. Nasuprot tome francuski pravni poredak je propisao obvezatnost sportskih osiguranja u slučajevima natjecateljskih sportskih priredbi. Francuski osiguratelji tako omogućuju osiguranje od posljedica nesretnog slučaja kojim se pruža pravna zaštita za slučaj sportskih ozljeda, kao i osiguranje od građanskopravne odgovornosti osiguranika za slučaj da

10 Stipić, M., Osiguranje s osnovama reosiguranja, Sveučilište u Splitu, Studijski centar za stručne studije, Split, 2008., str. 91.

11 Pravilnik o rasporedu vrsta rizika po skupinama i vrstama osiguranja odnosno reosiguranja, Narodne novine, br. 23/2016, 27/2016.

12 Aman, M.; Forssblad, M.; Henriksson-Larsén, K., Insurance claims data: a possible solution for a national sports injury surveillance system? An evaluation of data information against ASIDD and consensus statements on sports injury surveillance, vol. 4, no. 6, 2014., https://www.ncbi.nlm.nih.gov/ pmc/articles/PMC4067892/, 1. IX. 2018

13 Čurković, M., Mnogo rizika, malo osiguranja, Svijet osiguranja, br. 2, 2007., str. 49. 
je uzrokovao štetu trećoj osobi tijekom bavljenja sportom. ${ }^{14}$ Sukladno francuskom Zakonu o sportu ako sportska organizacija ne izvrši zakonsku obvezu sklapanja ugovor o osiguranju snosi kaznenopravne i građanskopravne sankcije. ${ }^{15}$

Za daljnju usporedbu sa hrvatskim realitetom u smislu primjerene osigurateljne zaštite sportaša i trećih osoba, korisno je istaknuti kako je režim obveznog sportskog osiguranja uveden u pravni sustav susjedne Srbije. Temeljem stroge zakonske obveze sportske organizacije koje djeluju u Srbiji dužne su sklopiti ugovor o osiguranju vrhunskih sportaša od rizika tjelesne ozljede uvjetovane nesretnim slučajem za vrijeme prakticiranja sportske aktivnosti. ${ }^{16} \mathrm{U}$ pravnoj teoriji se iznosi kritičko stajalište u odnosu na konkretan normativni koncept $\mathrm{s}$ obrazloženjem da je ono suviše restriktivno, budući da omogućuje pravnu zaštitu samo vrhunskim sportašima. Ujedno se predlaže reforma de lege ferenda sa ciljem da se umjesto sportskog rezultata za polazni kriterij zaštite uzme činjenica profesionalnog bavljenja sportom, a od rangiranja prema postignutim rezultatima može ovisiti suma osiguranja na koju se mora ugovoriti osiguranje. ${ }^{17}$

Kad je u pitanju hrvatski osigurateljni okvir, u pravnoj teoriji se upozorava da važeći Zakon o sportu $^{I 8}$ ne dotiče problematiku osiguranja u sportu bez obzira na iznimnu aktualnost teme koja je, između ostalog, uvjetovana vrhunskim sportskim rezultatima koje hrvatski sport ostvaruje na svjetskoj razini. Zatečeno stanje u tom pogledu se ocjenjuje kao manjkavo, sa čime se nije teško složiti. Istodobno se, u očitom nedostatku svijesti o potrebi uvođenja obvezatnih sportskih osiguranja, bar za neke vrste rizika, predlaže inkorporiranje jasne zakonske preporuke u tom smislu, što implicira adekvatnu dopunu propisa u bliskoj budućnosti. ${ }^{19}$

\section{PRAVA I OBVEZE UGOVORNIH STRANA}

\subsection{Općenito o načelu osigurljivog interesa}

Svaki ugovor o osiguranju pa tako i predmetni ugovor o osiguranju sportaša od nesretnog slučaja neće biti pravno valjan ukoliko osigurani rizik ne karakteriziraju određena svojstva. Tako se zahtijeva da osigurani rizik s obzirom na posljedice koje može izazvati pripada kategoriji tzv. čistih rizika, a nikako kategoriji špekulativnih

14 Gerald, S., Puissance sportive et ordre juridique étatique: contribution à l'étude des relations entre la puissance publique et les institutions privées, L.G.D.J, Paris, 1990., str. 319.

15 Čl. 321-331. Zakona o sportu, Francuska, 1962.

16 Zakon o sportu, Službeni list br. 2/07.

17 Mićović, M., Sport i osiguranje, Zbornik radova Pravnog fakulteta u Splitu, god. 49, br. 4, 2012 ., str. 741-749.

18 Zakon o sportu, Narodne novine, br. 71/06, 150/08, 124/10, 124/11, 86/12, 94/13, 85/15, 19/16.

19 Proso, M., Sportsko osiguranje, Zbornik radova Pravnog fakulteta u Splitu, god. 47, br. 2, 2010 ., str. 424. 
rizika. ${ }^{20}$ Teorija definira čist rizik kao situaciju u kojoj postoje samo dvije opcije, da se šteta dogodi ili da se ne dogodi, dok se s druge strane špekulativni rizik promatra kao situacija u kojoj je moguće ostvarenje profita ili gubitka. ${ }^{21}$ Istodobno špekulativni rizik nije osigurljiv u smislu da je na njega teže primijeniti pravila aktuarske matematike koje se zasnivaju na prije spomenutom zakonu velikih brojeva. Međutim, isto tako, nije niti svaki čisti rizik osigurljiv, da bi stekao to svojstvo mora u pravnom smislu ispuniti sljedeće kriterije ${ }^{22}$ in cumulo: (1) mora postojati velik broj jedinica izloženih riziku; (2) ostvarenje rizika (šteta) mora biti iznenadno, neizvjesno ali vjerojatno i nenamjerno; (3) rizik (šteta) mora biti odrediv i mjerljiv; (4) ostvareni rizik (šteta) ne smije biti katastrofalan; (5) vjerojatnost ostvarenja rizika (štete) mora biti kalkulabilno; (6) rizik mora biti pojedinačan ${ }^{23}$.

Izneseni obvezatni elementi proizlaze iz načela osigurljivog interesa koji utvrđuje da u slučaju nastanka osiguranog slučaja (štete) osiguranik mora pretrpjeti financijski gubitak ili neku drugu štetu. Naime, fundamentalna ideja instituta osiguranja jest da osiguranik nastankom osiguranog slučaja ne ostvari profit, jer premija osiguranja nije ulaganje u špekulativni rizik. $U$ tom smislu isplaćena osigurnina treba tek omogućiti popravljanje štete u vidu umanjenja i sanacije štetnih posljedica i to u najvećem mogućem financijskom volumenu, ali samo do stvarne vrijednosti štete. U literaturi se navodi kako inkorporacija načela osigurljivog interesa u strukturu ugovora o osiguranju ima dvojaku funkciju. ${ }^{24}$ Tako s jedne strane omogućuje mjerenje štete in concreto dok s druge strane, implementacija navedenog načela ima za svrhu prevenciju igara na sreću i moralnog hazarda, kao pojavama koje su pod određenim uvjetima protivne javnom moralu društva. Tako, primjerice, ne bi bilo moguće osigurati kuću i samovoljno uzrokovati štetu radi ostvarenja zarade, odnosno, u slučaju kad osiguranik trpi financijske posljedice zbog ostvarenog osiguranog slučaja u slučaju isplate osigurnine ne bi smio uprihoditi višak sredstava jer osigurnina ima za funkciju tek restituciju osiguranikovih interesa, dovođenje osiguranikovih stvari ili osobnih situacija u prvobitno stanje. Također, teorijska razrada modela „mjerenja rizika (štete)“ upućuje na krucijalni kriterij diferencijacije rizika koji se provodi s obzirom na činjenicu da li je osiguratelj u mogućnosti utvrditi veličinu rizika, tj., osigurateljnog pokrića. Sukladno tome, osigurljivi su svi rizici za koje postoje pretpostavke da im se može utvrditi veličina i stupanj pokrića, a pojavljuju se u tri osnovna oblika - osobni rizici, rizici od odgovornosti i imovinski rizici. ${ }^{25}$ Ako uzmemo u obzir pravnu konstrukciju kauze ugovora o osiguranju, koja je ranije pojašnjena i koja se jasno zasniva na elementu osigurljivog rizika, može se zaključiti da posebnu pretpostavku valjanosti svakog ugovora o osiguranju čini

20 Stipić, M., op. cit. u bilj. 22, str. 53.

21 Klobučar, D., op. cit. u bilj. 23, str. 10.

22 U ekonomskom smislu traži se još da premija bude ekonomski opravdana i prihvatljiva osiguraniku, a taj uvjet će se ispuniti pod uvjetom da je vjerojatnost nastanka štete relativno mala.

23 Stipić, M., op. cit. u bilj. 22, str. 54.

24 Klobučar, D., op. cit. u bilj. 23, str. 59.

25 Stipić, M., op. cit. u bilj. 22, str. 54. 
zahtjev da predmetom osiguranja mogu biti samo pojedinačni čisti osigurljivi rizici, sukladno najdubljim pobudama ugovaratelja osiguranja.

\subsection{Obveze ugovaratelja osiguranja i osiguranika}

\subsubsection{Općenito}

Za ugovaratelja osiguranja temeljem izričite zakonske odredbe i ugovorne stipulacije nastaju dvije osnovne obveze - obveza potpune i točne prijave te obveza plaćanja ugovorene premije u predviđenim rokovima. ${ }^{26}$ Osim navedenih obveza ugovaratelj osiguranja je dužan obavijestiti osiguratelja o promjenama okolnosti koja može biti važna za ocjenu osiguranog rizika. Odredbama citiranog zakona utvrđuju određene dužnosti na strani osiguranika od kojih posebno treba izdvojiti obvezu sprječavanja osiguranog slučaja, odnosno, ograničenja njegovih štetnih posljedica i spašavanja, te pridržavanja zaštitnih mjera. Također, normiraju se i druge specifične obveze osiguranika u situaciji kad nastane osigurani slučaj, primjerice, dužnost osiguranika da obavijesti osiguratelja o nastupu osiguranog slučaja u roku od 3 dana od saznanja.

\subsubsection{Obveza plaćanja premije}

Pojmovno, premija se definira kao novčani iznos koji ugovaratelj osiguranja plaća osiguratelju na temelju sklopljenog ugovora o osiguranju. ${ }^{27}$ Uplatom premije osiguratelj preuzima obvezu isplate osiguranog iznosa (osigurnine) u visini koja je određene ugovorom, u slučaju nastupa osiguranog slučaja. Drugim riječima, osiguratelj preuzima rizik prema ugovoru o osiguranju što per se predstavlja činidbu u korist ugovaratelja osiguranja (osiguranika; korisnika osiguranja), dok istodobno prima od ugovaratelja osiguranja novčani iznos na ime premije kao protučinidbu u zamjenu za obećanu prestaciju.

Dakle, ako se uzme u obzir causa ugovora sa svojim ekonomskim implikacijama tada se može jasno utvrditi da fundamentalna obveza ugovaratelja osiguranja, koja proizlazi iz ugovora o osiguranju, predstavlja upravo dužnost plaćanja premije osiguranja. U kontekstu dužnosti plaćanja premije bitno je istaknuti da navedena obveza koegzistira sa akcesornim i uzajamnim subjektivnim pravom osiguranika da bude oslobođen te obveze tako što je osiguratelj dužan primiti isplatu premije od svake osobe koja ima pravni interes da ona bude plaćena. Prema tome, dužnost plaćanja premije postoji istodobno sa dužnosti osiguratelja da primi plaćanje premije, temeljem načela uzajamnosti. ${ }^{28}$

\footnotetext{
26 Čl. 931-935. ZOO-a.

27 Rječnik osiguranja, Masmedia, Zagreb, 1997., str. 346.

28 Čl. 931-936. ZOO-a.
} 
Premija osiguranja se plaća u ugovorenim rokovima, a ukoliko je treba platiti odjednom tada se plaća prilikom sklapanja ugovora o osiguranju. U pogledu rokova plaćanja premije vrijedi opće pravilo da je ugovaratelj dužan platiti premiju, ako nije drukčije ugovoreno, odjednom za svaku godinu osiguranja. Osiguratelj ima pravo da sve neplaćene obroke premije tekuće godine osiguranja naplati prilikom bilo koje isplate iz temelja toga osiguranja. ${ }^{29} \mathrm{Kad}$ je ugovoreno kolektivno osiguranje (osiguranje bez naznake imena osiguranika), osiguranjem su obuhvaćene sve osobe koje se po službenim evidencijama vode kao aktivni članovi u polici određene sportske organizacije. U slučaju da su stranke dogovorile da se na kraju godine osiguranja izvrši konačni obračun premije prema prosječnom broju članova, osigurani iznosi koji su za svakog pojedinog osiguranika označene u polici ne mijenjaju se.

Premija se kod kolektivnog osiguranja plaća odmah unaprijed za cijelo vrijeme trajanja prema broju osiguranika označenom u popisu koji je priložen uz policu. Ali ako je ugovoreno da se na kraju godine osiguranja izvrši konačni obračun premije prema prosječnom broju članova, osigurani iznosi koji su za svakog pojedinog osiguranika označene u polici ne mijenjaju se. U tom slučaju premija se plaća odmah pri sklapanju ugovora za godinu dana unaprijed prema postojećem broju aktivnih članova i prema službenim evidencijama ugovaratelja na dan sklapanja ugovora, s tim da se konačni obračun premije izvrši na kraju godine trajanja osiguranja prema prosječnom brojnom stanju članova. Ugovaratelj je dužan ovlaštenom predstavniku osiguratelja staviti na uvid svoje evidencije iz kojih se može utvrditi stvarno brojno stanje članova, odnosno na njegov zahtjev podnijeti pismenu potvrdu nadležnog podsaveza o broju registriranih članova na dan nesretnog slučaja.

Ugovaratelj je obvezan ugovorenu premiju plaćati osiguratelju za sve osiguranike bez iznimke i za cijelo vrijeme trajanja osiguranja u roku označenom u polici. ${ }^{30}$

\subsubsection{Obveza prijave okolnosti značajnih za ocjenu osiguranog rizika}

U pogledu obveze potpune i točne prijave ugovaratelj osiguranja je dužan prijaviti osiguratelju prilikom sklapanja ugovora sve okolnosti koje su značajne za ocjenu rizika, a koje su mu poznate ili mu nisu mogle ostati nepoznate. Međutim, ako je ugovaratelj osiguranja namjerno učinio netočnu prijavu ili namjerno prešutio neku okolnost takve naravi da osiguratelj ne bi sklopio ugovor da je znao za pravo stanje stvari, osiguratelj može zahtijevati poništaj ugovora. U slučaju nenamjerne netočnosti ili nepotpunosti prijave osiguratelj može, po svom izboru, u roku od mjesec dana od saznanja za netočnost ili nepotpunost prijave izjaviti da raskida ugovor ili predložiti povećanje premije razmjerno povećanom riziku. Osiguratelj se ne može pozivati na netočnost ili nepotpunost prijave ako su mu u trenutku sklapanja ugovora bile poznate ili mu nisu mogle ostati nepoznate okolnosti koje

29 Čl. 10. Općih uvjeta Croatia osiguranja d.d.

30 Čl. 7. Dopunskih uvjeta Croatia osiguranje d.d. 
su značajne za ocjenu rizika, a koje je ugovaratelj osiguranja netočno prijavio ili prešutio.

\subsection{Obveze osiguratelja}

\subsubsection{Općenito}

Temeljne obveze osiguratelja proizlaze iz odredbi ZOO-a ${ }^{31}$ te se odnose na više grupa obveza od kojih se kao središnja ističe dužnost isplate osigurnine u visini koja je određene ugovorom u slučaju nastupa osiguranog slučaja. Preostale standardne obveze osiguratelja tiču se obveze primitka plaćanja premije od svake osobe koja ima pravni interes da ona bude plaćena, obveze u pogledu franšize (ugovoreni samopridržaj) ako je ugovorena, a napose obveza glede utvrđivanja, procjene i vještačenja štete o čemu više u narednim poglavljima.

\subsubsection{Obveza osiguratelja na isplatu osigurane svote (osigurnina)}

Klasična definicija pojma osigurnine podrazumijeva ispunjenje obveze osiguratelja kao završne faze temeljnih postavki funkcioniranja sustava osiguranja, a koja se temelji na načelu uzajamnosti i solidarnosti budući da ugovaratelj osiguranja udružuje određeni iznos (premija osiguranja) u društvo za osiguranje, a osiguratelj se obvezuje da, kad nastane osigurani slučaj (rizik), isplati osiguraniku ili nekoj trećoj osobi naknadu (u slučaju imovinskih osiguranja) odnosno ugovorenu svotu (u slučaju osiguranja osoba) ili učini nešto drugo. ${ }^{32}$ Kad je u pitanju osiguranje osoba, kojemu pripada predmetni ugovor o osiguranju, ispunjenje obveze osiguratelja sastoji se u isplati ugovorene svote kad nastupi osigurani slučaj, a utvrđuje se postupkom koji se interno naziva likvidacija štete (obveze). Utvrđujući pravne pretpostavke isplate osigurnine zakonodavac je propisao da je u slučaju nastupa osiguranog slučaja osiguratelj dužan isplatiti osigurninu određenu ugovorom u ugovorenom roku koji ne može biti dulji od četrnaest dana, računajući otkad je osiguratelj dobio obavijest da se osigurani slučaj dogodio. Međutim, ako je za utvrđivanje postojanja osigurateljeve obveze ili njezina iznosa potrebno stanovito vrijeme, osiguratelj je dužan isplatiti osigurninu određenu ugovorom u roku od trideset dana od dana primitka odštetnog zahtjeva ili ga u istom roku obavijestiti da njegov zahtjev nije osnovan. Ukoliko iznos osigurateljeve obveze ne bude utvrđen u navedenim okovima osiguratelj je dužan bez odgađanja isplatiti iznos nespornog dijela svoje obveze na ime predujma. ${ }^{33}$

31 Čl. 931-942. ZOO-a.

32 Stipić, M., op. cit. u bilj. 22, str. 61.

33 Čl. 943. ZOO-a. 


\subsubsection{Opseg osigurateljnog pokrića}

Sukladno odredbama analiziranog ugovora o osiguranju sportaša od nesretnog slučaja, kad nastane nesretni slučaj osiguratelj isplaćuje iznose ugovorene u ugovoru o osiguranju i to: (1) osigurani iznos za slučaj smrti, ako je zbog nesretnog slučaja nastupila smrt osiguranika, (2) osigurani iznos za slučaj trajnog invaliditeta ako je zbog nesretnog slučaja nastupio potpuni (100\%) invaliditet osiguranika; (3) postotak od osiguranog iznosa za slučaj invaliditeta koji odgovara postotku djelomičnog invaliditeta, ako je zbog nesretnog slučaja nastupio djelomični invaliditet osiguranika; (4) dnevnu naknadu zbog privremene nesposobnosti za rad odnosno za obavljanje svog redovitog zanimanja; (5) dnevnu naknadu za boravak u bolnici zbog liječenja od posljedica nesretnog slučaja; (6) naknadu troškova liječenja, ako je osiguraniku zbog nesretnog slučaja bila potrebna liječnička pomoć i ako je uslijed toga imao troškove liječenja; (7) ostale ugovorene obveze prema posebnim ili dopunskim uvjetima. ${ }^{34}$

Prvenstveno treba naglasiti da iznos osigurane svote nije ograničen te je predmet slobodnog ugovaranja između osiguratelja i ugovaratelja osiguranja. Naime, sukladno zakonu, u ugovorima o osiguranju osoba (osiguranje života i osiguranje od nesretnog slučaja), visina osiguranog iznosa koji je osiguratelj dužan isplatiti kad nastupi osigurani slučaj utvrđuje se u polici prema sporazumu ugovornih strana. ${ }^{35}$ Osiguratelj je u obvezi ako nesretni slučaj nastane u jednom od slijedeća tri slučaja: (1) pri sportskoj djelatnosti osiguranika u onoj grani sporta koja je u polici izričito navedena, kao i u svim drugim granama koje prema rasporedu sportova u cjeniku premija spadaju u isti ili niži razred opasnosti od sporta koji je naveden u polici, (2) za vrijeme dok se osiguranik nalazi na izravnom (neprekidnom) putu i izvan sjedišta sportske organizacije čiji je član i to od kuće do određenog vježbališta ili mjesta određenog za natjecanje i na povratku kući, (3) pri obavljanju određenih dužnosti po nalogu uprave sportskog društva, i to: sudjelovanje na sportskim sastancima, konferencijama, nabavka sportskih rekvizita i sl., kao i za vrijeme dok se nalazi na putu u svezi s obavljanjem ovih poslova. ${ }^{36}$

Iznos osigurateljne premije je inter alia determiniran razredom opasnosti unutar kojeg je pojedini sport razvrstan prema uvjetima osiguranja. Primjerice, opasnosti od elektronskog pikada, bridž i drugi sportovi koji ne nose značajan stupanj rizika od nastupa nezgode, zatim, hokej na travi, kajak na mirnim vodama, rafting, kao sportovi koji nose povećani rizik, te konačno grupa najopasnijih sportova poput moto utrka, borilačkih sportova i sl. Osiguratelj je u obvezi isplatiti osigurninu pod uvjetom da se nesretni slučaj zbio tijekom bavljenja onim sportom koji je naveden u ugovoru o osiguranju ili u sportu koji je klasificiran u niži razred opasnostiMeđutim, u situaciji kad nesretni slučaj nastane pri sportskoj djelatnosti osiguranika u onoj grani sporta koja nije u polici izričito navedena, a koja spada u teži razred opasnosti od sporta koji je naveden u polici, osiguratelj je obvezan isplatiti smanjeni

34 Čl. 7. Općih uvjeta Croatia osiguranja d.d.

35 Čl. 966.ZOO-a.

36 Čl. 3. Dopunskih uvjeta Croatia osiguranja d.d. 
osigurani iznos koja odgovara omjeru između premije koju bi trebalo platiti za dotični teži razred opasnosti i plaćene premije. ${ }^{37}$

\subsubsection{Posebno o opsegu osigurateljnog pokrića u hrvatskoj osigurateljnoj ponudi te ad comparandum}

Tematika opsega osigurateljnog pokrića sportskih ozljeda u hrvatskoj osigurateljnoj praksi bila je predmetom sumarne poredbenopravne analize. Tako je pored predmetnog ugovora o osiguranju sportaša od sportskih ozljeda, a koji je bazično odabran za svrhe ovog istraživanja, usporedno istražen ugovor drugog europskog osiguratelja koji nudi osiguranje sportaša od istih rizika uslijed nezgode. Tako je prema paralelnom premijskom sustavu u ponudi drugog osiguratelja moguće ugovoriti osiguranje od nezgode za članove sportskih organizacija: sportaša amatera i sportaša profesionalca. Ugovaratelji osiguranja su sportske organizacije, a osiguranje se ugovara za njihove članove. Osiguranje se može ugovoriti kao pojedinačno ili grupno. U oba slučaja premijske stope ostaju nepromijenjene, a popust na broj osiguranika se ne primjenjuje. Premija se određuje prema razredu opasnosti u koji je raspoređena sportska aktivnost koja se osigurava. Osim sportske aktivnosti navedene na polici osiguranja, pokriveni su i ostali sportovi koji spadaju $\mathrm{u}$ isti ili niži razred opasnosti. Maksimalno trajanje osiguranja je jedna (1) godina. ${ }^{38}$ Dakle, prema odredbama potonjeg ugovora, ugovoreno osiguranje obuhvaća nesretne slučajeve (nezgode) koje se članovima sportskih organizacija i društava (sportašima) mogu dogoditi za vrijeme bavljenja sportom za koji se ugovara osigurateljno pokriće (pripreme, treninzi, natjecanja). Uključeni su nesretni slučajevi (nezgode) na direktnom putu do i od mjesta bavljenja sportom. Osigurateljna zaštita ne vrijedi ako se direktni uobičajeni put do i od mjesta na kojem se obavlja sportska aktivnost prekine ili produži, osim ako su prekid puta ili odstupanje od uobičajenog puta u vezi s obavljanjem sportske aktivnosti ili su uzrokovani humanim razlozima. Uz odgovarajuću nadoplatu, osiguranje vrijedi 24 h, odnosno i izvan vremena bavljenja sportom za koji se ugovara osigurateljno pokriće. Osim sporta za koji se ugovara osigurateljno pokriće, pokriveni su i ostali sportovi koji spadaju u isti ili niži razred opasnosti. ${ }^{39}$

Usporedna analiza ova dva spomenuta ugovora o osiguranju sportaša od sportskih ozljeda je neprijeporno potvrdila, inače notornu spoznaju svih uključenih u osigurateljni život Hrvatske, da se u pravnom smislu radi o temeljno identičnom ugovornom obrascu u pogledu svih bitnih sastojaka ugovora, definicije pravno relevantnih pojmova, per exemplum, nesretnog slučaja, te u pogledu predmeta osiguranja, odnosno, osiguranih rizika. Pravne razlike se mogu uočiti isključivo u pogledu neki dodatnih klauzula kojima se mogu ugovoriti posebna pokrića u vezi

37 Ibid.

38 UNIQA d.d., Zagreb, Opći uvjeti osiguranja od nezgode za članove sportskih organizacija

39 Osiguranje od posljedica nesretnog slučaja (nezgode) - sportske organizacije i društva, Uvjeti osiguranja N-Kl-007/01-14, 2018., UNIQA d.d., Zagreb 
sa nastupom nesretnog slučaja. S druge strane, značajnije varijacije u ugovorima su tek ekonomske naravi i nisu bile predmetom ovog istraživanja.

\subsubsection{Dodatne obveze osiguratelja na ime dodatnih rizika}

Ugovorom je moguće dodatno uglaviti osiguranje dodatnih rizika - dnevne naknade i dnevne naknade u bolnici - uz obveznu karencu u trajanju koja se upisuje u policu osiguranja. Osiguratelj nije u obvezi isplate dnevne naknade za vrijeme ugovorenog vremenskog isključenja osigurateljnog pokrića (karence). Ako je ugovoreno osiguranje i za slučaj privremene nesposobnosti za rad, osiguratelj isplaćuje osiguraniku koji uslijed nesretnog slučaja nije sposoban za rad, dnevnu naknadu u ugovorenoj visini i to počev od desetog dana od dana započetog liječenja, ukoliko drukčije nije ugovoreno, a najviše za 200 dana. Pri tome se uzima u obzir za sportaše amatere samo vrijeme za koje je osiguranik bio nesposoban za obavljanje poslova svog redovnog zanimanja, a ne i vrijeme kada je bio nesposoban za sudjelovanje u sportskoj aktivnosti označenoj u polici. Za sportaše profesionalce uzima se u obzir vrijeme za koje je osiguranik bio nesposoban za sudjelovanje u sportskoj aktivnosti (trening i natjecanje) označene u polici koja predstavlja njegovo redovno zanimanje. ${ }^{40}$

Ugovorom o osiguranju sportaša od nesretnog slučaje moguće je posebno ugovoriti naknadu za lom kosti - klauzula lom kosti. Naime, ukoliko osigurani slučaj ima za posljedicu prijelom kosti osiguranika koji je dokazan RTG snimkom, a nije nastupila smrt osiguranika, osiguratelj isplaćuje ugovorenu naknadu po štetnom događaju neovisno o broju slomljenih kostiju odnosno ocjene trajnog invaliditeta. Osigurateljno pokriće kosti ne postoji u slučaju nastupa epifiziolize te kod bolesnih stanja poremećaja u čvrstoći i građi kosti (osteoporoza, osteomalacija te ostale osteopatije) kao niti kod drugih patoloških prijeloma kostiju. ${ }^{41}$

Osiguratelji ponekad svojim uvjetima osiguranja omogućuju sportašima da se osiguraju od dodatnih rizika koji nisu u uzročnoj vezi sa sportskom aktivnosti. Tako postoji opcija dodatnog osiguranja od posljedica nesretnog slučaja i u svakodnevnom životu sportaša ( 24 satno osiguranje) uz plaćanje doplatne premije.

\subsubsection{Isključenje obveze osiguratelja}

U prvom redu treba se napomenuti da je ugovor o osiguranju ništetan, ako je u trenutku njegovog sklapanja već nastao osigurani slučaj ili je bio u nastupanju ili je bilo izvjesno da će nastupiti, a uplaćena premija vraća se ugovaratelju umanjena za troškove osiguratelja. S druge strane, zakon je explicite isključio obvezu osiguratelja na isplatu osigurane svote u taksativno navedenim slučajevima: (1) samoubojstvo osiguranika; (2) namjerno ubojstvo osiguranika; (3) namjerno prouzročenje

40 Čl. 10. Dopunskih uvjeta Croatia osiguranja d.d.

${ }_{41}$ Čl. 11. Dopunskih uvjeta Croatia osiguranja d.d. 
nesretnog slučaja, i u (4) slučaju ratnih operacija. ${ }^{42}$ Tako se propisuje da u slučaju namjernog ubojstva osiguranika od strane korisnika osiguranja, osiguratelj nije u obvezi da korisniku isplati osigurani iznos. Također, osiguratelj se oslobađa obveze iz ugovora o osiguranju od nesretnog slučaja ako je osiguranik namjerno prouzročio nesretni slučaj. Ako nije što drugo ugovoreno, osiguratelj se oslobađa obveze iz ugovora o osiguranju od nesretnog slučaja, ako je nesretni slučaj prouzročen ratnim operacijama. Ugovorom o osiguranju za slučaj smrti ili od nesretnog slučaja mogu biti isključeni iz osiguranja i drugi rizici kao što je to redovito slučaj. Prema odredbama općih i dopunskih uvjeta ugovora o osiguranju sportaša isključeni su iz osiguranja i neki drugi rizici koji bi mogli biti u kauzalnoj vezi sa obavljanjem konkretne sportske aktivnosti ili se tiču zdravstvenog stanja osiguranika bilo da se radi o privremenom stanju induciranom zabranjenom konzumacijom određenih tvari ili nekim psiho-organskim smetnja koje nisu bile poznate. Dakle, prema dopunskim uvjetima isključene su u cijelosti sve obveze osiguratelja, ako je nesretni slučaj u cijelosti ili djelomično nastao, odnosno, ako je neposredno ili posredno prouzročen ili kojem nastanku je doprinijelo ili ga učinilo težim slijedeće situacije okolnosti: (1) prilikom sudjelovanju u tučnjavi bilo na sportskom terenu ili izvan njega, kada je bilo izvjesno da je osiguranik tučnjavu započeo ili ju je aktivno prihvatio; (2) ako je osiguranik pod utjecajem alkohola ili pod utjecajem droge ili narkotika čije je konzumiranje suprotno zakonu, osim ako ih osiguraniku nije prepisao kvalificirani liječnik ili je konzumirao lijekove ili tvari koje su zabranjene ili suprotne pravilniku regulatornog tijela nadležnog za sport u kojem osiguranik igra; (3) osiguranikovo konzumiranje tvari koje povećavaju snagu i učinkovitost, što uključuje, ali nije ograničeno na anabolične steroide, stimulanse i kortikosteroide, bez obzira na to je li ih prepisao kvalificiraniliječnik; (4) bilo koji postupci ili aktivnosti koji su isključeni amaterskim ili profesionalnim sportskim ugovorom osiguranika i u vezi s njegovim zanimanjem navedenim u ugovoru; (5) stanja psihotičnog, psihoneurotičnog ili epileptičnog porijekla. osteoartritis, artritis ili druga degenerativna bolest zglobova, kostiju, tetiva ili ligamenata.

U slučaju da osiguratelj ustanovi da je osiguranik usprkos preporuci ili zabrani liječnika (koji ga je liječio u slučaju ozljede zbog koje je izbivao s sportskih terena,) trenirao i/ili nastupao na natjecanjima ili sudjelovao u sportu pokrivenim ovim osiguranjem, osigurateljna obveza ne postoji. U tome slučaju smatra se da je osiguranik samostalno preuzeo rizik nastupa nesretnog slučaja na sebe jer je rizik tada bioizvjestan. Ako osiguranik kao vozač ili putnik u trenutku nastupa nesretnog slučaja nije koristio zaštitnu kacigu ili nije bio vezan sigurnosnim pojasom sukladno odredbama Zakona o sigurnosti prometa na cestama. Za sportaša profesionalca osiguratelj nije u obvezi ukoliko tjelesna povreda nije definirana na opisani način u čl. 1 . st. $5 .{ }^{43}$

42 Čl. 973-977 ZOO-a.

43 Čl. 4. Dopunskih uvjeta Croatia osiguranja d.d. 
Opći uvjeti osiguranja navode drugu grupu generalnih rizika koji isključuju obvezu osiguratelja na isplatu osigurnine, a koji se dijelom pokapaju sa prethodno iznesenim zakonskim razlozima isključenjima. ${ }^{44}$

\subsection{Osigurani slučaj}

\subsubsection{Općenito}

Opći pojam rizika označava budući neizvjestan događaj koji može imati nepoželjne posljedice bez obzira na to kako je nastao ili je izazvan. Rizik se ne smije poistovjetiti sa neizvjesnosti koja je tek sastavni dio pojma rizika i predstavlja nesposobnost anticipacije nekog događaja ili ishoda. Drugi riječima, neizvjesnost jest situacija kad vjerojatnost nekog događaja nije poznata. Bitno je napomenuti da hrvatska i međunarodna osigurateljna praksa generalno prihvaćaju, mutatis mutandis, sljedeće osnovne oblike osiguranja profesionalnih sportaša od posljedica nesretnog slučaja: (1) privremenu nesposobnost za rad, odnosno, privremenu potpunu nesposobnost (temporary total disablement), (2) djelomični ili trajni invaliditet, odnosno, trajnu potpunu nesposobnost (permanent total disablement) i (3) smrt uslijed nesretnog slučaja (accidental death). Osiguranje od privremene potpune nesposobnosti pokriva sportaša dok je privremeno onesposobljen za igru uslijed ozlijede ili bolesti, dok osiguranje od trajne potpune nesposobnosti pokriva slučajeve ozljeda koje dovode do kraja karijere ili potpune sportske nesposobnosti (sportski invaliditet). ${ }^{45}$

\subsubsection{Tipologija sportskih ozljeda}

Prema standardnoj definiciji, tjelesna ozljeda predstavlja svaki poremećaj u strukturi i funkcionalnosti određenog dijela tijela nastao u određenom i ograničenom

44 U osnovi radi se o rizicima od nastupa nezgode koji bi se mogli povezati sa izvanrednim ratnim i revolucionarnim okolnostima, terorizmom, neovlaštenim upravljanjem raznim vrstama vozila, sa postupanjem osiguranika koje ima obilježja kaznenog djela i dr. Slijedom toga, osiguratelj neće biti u obvezi isplatiti osigurani iznos ako nesretni slučaj nastane iz sljedećih uzroka: zbog potresa; zbog objavljenog rata u našoj državi; zbog ratnih događaja, neprijateljstava ili ratu sličnih radnji, građanskoga rata, revolucije, pobune, ustanka ili građanskih nemira koji nastanu iz takvih događaja, sabotaže ili terorizma počinjenog iz političkih pobuda, nasilja ili drugih sličnih događaja u kojima je sudjelovao osiguranik; pri upravljanju letjelicama svih vrsta, plovnim objektima, motornim i drugim vozilima bez propisane službene isprave koja daje ovlaštenje vozaču za upravljanje i vožnju tom vrstom i tipom letjelice, plovnog objekta, motornog i drugog vozila; zbog pokušaja ili izvršenja samoubojstva osiguranika; zbog toga što je ugovaratelj osiguranja, osiguranik ili korisnik namjerno prouzročio nesretni slučaj; pri pripremanju, pokušaju ili izvršenju kaznenog djela s umišljajem, kao i pri bijegu poslije takve radnje; zbog djelovanja alkohola, opojnih droga ili lijekova na osiguranika, bez obzira na bilo kakvu odgovornost treće osobe na nastanak nesretnog slučaja. Smatra se da je nesretni slučaj nastao zbog djelovanja alkohola samo ako je takvo alkoholizirano stanje osiguranika imalo uzročnu vezu s nastankom nesretnog slučaja., Čl. 9. Općih uvjeta Croatia osiguranja d.d.

45 Link Brokeri d.d., Zagreb, Uvjeti osiguranja profesionalnih sportaša od rizika nezgode te privremene ili trajne potpune nesposobnosti. 
vremenu bilo fizikalnim (struja, toplina), kemijskim (kiseline, lužine) ili mehaničkim (udarac, pad, ubod, prostrjel) uzrokom, a koji, u većoj ili manjoj mjeri, smanjuje mogućnost za obavljanje svakodnevnih aktivnosti. Kad je u pitanju osiguranje važno je napraviti distinkciju između tjelesne ozljede i oštećenja. ${ }^{46} \mathrm{~S}$ obzirom na moguće uzroke i modalitete nastanka sportskih ozljeda one mogu nastati kao posljedica izravnog kontakta s drugim sportašem ili bez tog kontakta. Per exemplum to mogu biti situacije kada sportaš pretrpi udarac u tijelo ili se sudari sa drugim sportašem tijekom igre, ili kad pretrpi ozljedu pri padu, naglim pokretom dijela tijela (rotacije) na podlozi i sl. Na nastanak i težinu tjelesne ozljede može utjecati i tip sportske podloge na kojoj se održava sportska priredba, meteorološki uvjeti koji mogu uvjetovati skliskost terena itd. U stručnoj literaturi se navodi podatak kako je rizik od tjelesne povrede čak 12 puta veći za vrijeme natjecateljskih utakmica španjolske profesionalne nogometne lige nego za vrijeme treninga i priprema. Kad su u pitanju tipovi ozljeda profesionalnih nogometaša iste lige najčešće se bilježe povrede mišićnog tkiva koje u pravila zahtijeva do tjedan dana liječenja. ${ }^{47}$

Sukladno klasifikaciji sportova, koja se osniva na vrhunskim dinamičkim i statičkim opterećenjima tijekom natjecanja, sportove možemo razlikovati prema vrsti i količini opterećenja koje oni zahtijevaju prilikom igranja. ${ }^{48}$ Tako u sportove visokog dinamičkog opterećenja ubrajamo: badminton, skijaško trčanje (klasična tehnika), orijentacijsko trčanje, brzo hodanje, trčanje na duge pruge, nogomet, squash, tenis (pojedinačno), košarka, hokej na ledu, skijaško trčanje (klizačka tehnika), nogomet (australska pravila), kros trčanje, trčanje na srednje pruge, plivanje, rukomet, boks, kajak/kanu biciklizam, desetoboj, veslanje vaterpolo i klizanje.

\subsubsection{Pravno relevantna tjelesna povreda u profesionalnom sportu}

Za sportaša profesionalca osiguratelj nije u obvezi ukoliko tjelesna povreda nije definirana na način znači specifičnu fizičku povredu prouzročenu nesretnim slučajem, odnosno, takvu povredu koja je izravna posljedica nesretnog slučaja i nije nastala zbog kumuliranja niza nesretnih slučajeva ili povreda i ako je nisu izravno ili neizravno prouzročili, ako joj nisu doprinijeli i/ili je pogoršali, fizičko oštećenje,

46 Za razliku od tjelesne ozljede pod oštećenjem se smatra patološko-anatomski supstrat koji se anamnestički ne može dokazati, a profesionalni sportaš ili rekreativac najčešće je uopće nije osjetio ili se ne može sjetiti vremena nastanka oštećenja (Mišković 2011), te je u pravilu posljedica niza uzastopnih mikrotrauma (Pećina 2004). Prema tome bitno svojstvo je akutnost nastanka, dok je oštećenje kroničnog karaktera. U tom smislu, prema kriteriju vremenu kad su nastale ozljede možemo podijeliti na akutne i kronične, pri čemu akutne ozljede nastaju djelovanjem relativno jake sile (u kontaktu ili sile kontrakcije vlastitog mišićnog sustava) na dio tijela u kratkom vremenu, dok kronične nastaju opetovanim djelovanjem sile slabijeg intenziteta (sindrom prenaprezanja). Sportske ozljede većinom se odnose na sustav za pokretanje, a sama ozljeda je uglavnom traumatske prirode. (istegnuće, iščašenje, ruptura, prijelom, otrgnuće).

47 Asociación RUVID. Injuries of professional soccer players twelve times more frequent in competition than during training sessions?. ScienceDaily, 17 February 2015. www.sciencedaily.com/ releases/2015/02/150217083932.htm, 1. IX. 2018.

48 Mišigoj-Duraković, M. Tjelesno vježbanje i zdravlje: znanstveni dokazi, stavovi, preporuke. Grafos: Fakultet za fizičku kulturu, Zagreb, 1999., str. 168. 
mana, degenerativna bolest ili druga bolest koja je postojala prije ugovaranja osiguranja. Pri tome rečeno fizičko oštećenje, nedostatak, mana i/ili bolest moraju postojati prije ugovaranja osiguranja, a u slučaju da nisu bile dijagnosticirane prije stupanja na snagu ovoga osiguranja, ako ih je, po mišljenju liječnika cenzora, osiguranik mogao biti svjestan na datum stupanja na snagu ugovora o osiguranju. ${ }^{49}$

\subsubsection{Opasni sportovi}

Glede specifičnih sportova koje osiguratelji ocjenjuju posebno opasnim vrijedi pravilo da ako je izričito ugovoreno i ako je plaćena odgovarajuća premija, osiguratelj će biti obvezan isplatiti osigurani iznos ili njezin dio u punom iznosu i kad su u pitanju sportovi najvišeg razreda opasnosti. A contrario, ako nije ništa ugovoreno i nije plaćena odgovarajuća premija, obveza osiguratelja ne postoji kad nesretni slučaj nastane pri sudjelovanju u automobilskim i motociklističkim utrkama, rallyu i cartingu, kao i treningu za njih, te pri sportskim skokovima padobranom, pri vožnji i upravljanju zrakoplovom i letjelicama svih vrsta, osim u svojstvu putnika u javnom prijevozu. ${ }^{50} \mathrm{U}$ teoriji se napominje da je za osiguranje opasnih (ekstremnih) sportova koje nose povećani rizik od nastanka štete, tipično da često u praksi nositelji sportskih aktivnosti nisu spremni sklopiti ugovor o osiguranju zbog nešto više cijene premije, a nerijetko niti osiguratelji nisu spremni uvrstiti u osigurateljnu ponudu takvo osiguranje. ${ }^{51}$ Kao moguće rješenje u smjeru pružanja učinkovite pravne zaštite predlaže se propisivanje obvezatnog osiguranja poput primjerice Francuske koja je to normirala u odnosu na neke opasne sportove. ${ }^{52}$

\subsubsection{Pravna konstrukcija osiguranog slučaja}

Osigurani slučaj je događaj prouzročen osiguranim rizikom. ${ }^{53} \mathrm{U}$ pogledu karakteristika takvog događaja (nezgode) potrebno je apostrofirati kako nije apstraktne naravi, niti bi mogao predstavljati situaciju čiji nastanak je vrlo vjerojatan ili je pak u nastajanju. Naprotiv, osigurani slučaj (događaj) se mora zasnivati na objektivnoj činjenici koja je nastala u budućnosti u neizvjesnim okolnostima, te izvan volje sukontrahenata ugovora o osiguranju. Sukladno zakonu, rizik koji je obuhvaćen osiguranjem (osigurani rizik) mora biti budući, neizvjestan i nezavisan od isključive volje ugovaratelja osiguranja ili osiguranika.

U pravnoj literaturi se navodi kako se pojam nezgoda (nesretni slučaj) odnosi na seriju manifestiranih okolnosti koje su prouzrokovale štetu pri čemu se pojam "šteta" odnosi na određene štetne posljedice nastale u svakom pojedinačnom slučaju. ${ }^{54}$ Tako se u hrvatskoj i europskoj osigurateljnoj praksi pod nesretnim slučajem

49

50 Ibid.

51 Proso, M., op. cit. u bilj. 19, str. 42.

52 Mićović, M., op. cit. u bilj. 17, str. 745.

53 Čl. 922. ZOO-a.

54 Chrissanthis, C., op. cit. u bilj. 82, str. 21. 
(nezgodom) smatra svaki iznenadan i o volji osiguranika nezavisan događaj koji, djelujući uglavnom izvana i naglo na tijelo osiguranika, ima za posljedicu njegovu smrt, potpuni ili djelomični trajni invaliditet, prolaznu nesposobnost za rad ili narušenje zdravlja koje zahtjeva liječničku pomoć, odnosno liječenje u bolnici. ${ }^{55}$

U cilju prevencije eventualnog nerazumijevanja prividne terminološke divergencije neophodno je ustanoviti istovjetnost sadržaja pojmova osiguranog slučaja i nesretnog slučaja. Neovisno o činjenici što zakonodavac i osigurateljna praksa ponekad koriste drukčije stručno nazivlje, već je prima facie evidentno da se radi o istovjetnom kompleksu okolnosti - događaju sa identičnim obilježjima. Naime, oba pojma se odnose na događaj čiji kauzalni supstrat predstavlja ostvarenje osiguranog rizika u vidu kvalificiranog narušenja zdravlja sa pratećim posljedicama, a pri čemu se događaj mora dogoditi u budućnosti, iznenadno i nepredvidivo (neizvjesno), te bez utjecaja zainteresiranih strana ugovora o osiguranju u pogledu njegovog nastanka. Naime, prema uvjetima analiziranog ugovora o osiguranju sportaša od nesretnog slučaja pod pojmom nesretnog slučaja razumijeva se svaki iznenadni i od volje osiguranika nezavisni događaj koji, djelujući uglavnom izvana i naglo na tijelo osiguranika, ima za posljedicu njegovu smrt, potpuni ili djelomični invaliditet, privremenu nesposobnost za rad ili narušenje zdravlja koje zahtijeva liječničku pomoć. ${ }^{56}$ Drugi osiguratelji pod nezgodom (nesretnim slučajem) podrazumijevaju pojedinačan, iznenadan i nepredvidiv događaj koji se dogodio na poznatom mjestu i u poznato vrijeme i koji je direktno i neovisno uzrokovao tjelesno oštećenje ili smrt i koje nije uvjetovano niti u uzročno-posljedičnoj vezi s bilo kojim prethodnim stanjem osiguranika.

In fine, može se ustvrditi da u osnovi pravnog konstrukta osiguranog slučaja, odnosno, nesretnog slučaja (nezgode), stoji sasvim određena, konkretna i faktična situacija koja je u kauzalnom odnosu sa osiguranim rizikom koji uvijek opstoji kao hipotetička kategorija s obilježjem asertivnosti, budući da svoje postojanje in abstracto ne duguje drugom uzroku.

\subsection{Pravne pretpostavke i postupak naplate osigurnine}

\subsubsection{Faze naplate osigurnine}

U slučaju nastupa osiguranog slučaja zakon i osigurateljni uvjeti precizno propisuju proceduru naplate osiguranog iznosa na osnovu činjenice da je ostvaren ugovoreni osiguranik rizik uslijed nezgode sportaša tijekom obavljanja sportske aktivnosti. Tako će redovni postupak naplate proći nekoliko konsekutivno povezanih faza prije eventualne isplate osigurnine u cilju utvrđenja prijeko potrebnih pretpostavki koje moraju biti ispunjene prije isplate osigurnine. U prvom redu se normira obveza obavješćivanja o nastupanju osiguranog slučaja, odnosno, prijava

55 Čl. 6. Općih uvjeta za osiguranje od nezgode, 2018.,UNIQA d.d., Zagreb

56 Čl. 5. Općih uvjeta Croatia osiguranja d.d. 
nesretnog slučaja kako to određuje ugovor o osiguranju, zatim, utvrđivanje prava korisnika na naknadu koji može uključivati provođenje prethodnog vještačenja na relevantne okolnosti, te konačno, isplata osiguranog iznosa.

\subsubsection{Prijava nastupa osiguranog slučaja}

Sintagma prijava osiguranog slučaja (̌̌tetnog događaja) podrazumijeva obavijest koju je prema ugovoru o osiguranju osiguranik ili korisnik osiguranja iz police dužan dati osiguratelju kad nastane osigurani slučaj. ${ }^{57}$ Sukladno pozitivnim propisima RH osiguranik ima obvezu obavijestiti o nastupanju osiguranog slučaja najdalje u roku od tri dana otkad je to saznao pod prijetnjom naknade štete osiguratelju ukoliko tu obvezu ne bi ispunio na vrijeme. ${ }^{58} \mathrm{U}$ pogledu obveze informiranja o nastalom osiguranom slučaju, odnosno, obveze prijave nesretnog slučaja, analizirani ugovor o osiguranju sportaša zahtijeva od osiguranika koji je pretrpio ozljedu da se: (1) odmah prijavi liječniku odnosno pozove liječnika radi pregleda i pružanja potrebne pomoći i poduzimanja svih potrebnih mjera radi liječenja kao i da se drži liječničkih savjeta i uputa u pogledu načina liječenja; (2) da o nesretnom slučaju pismom izvijesti osiguratelja u roku kada mu to prema njegovom zdravstvenom stanju bude moguće; (3) da s prijavom o nesretnom slučaju pruži osiguratelju sva potrebna izvješća i podatke naročito o mjestu i vremenu kada je slučaj nastao, potpuni opis događaja, ime liječnika koji ga je pregledao i uputio na liječenje ili koji ga liječi, nalaz liječnika o vrsti i težini ozljede, o nastalim eventualnim posljedicama, kao i podatku o manama, nedostacima i bolestima koje je eventualno osiguranik imao prije nastanka nesretnog slučaja.

Ako je nesretni slučaj imao za posljedicu smrt osiguranika, korisnik osiguranja je dužan o tome pismom izvijestiti osiguratelja i pribaviti potrebnu medicinsku i ostalu dokumentaciju. Osiguratelj je ovlašten tražiti naknadna objašnjenja i dokaze, te na svoj trošak poduzeti radnje u svrhu liječničkog pregleda osiguranika putem svojih liječnika ili liječničkih komisija da bi se utvrdile važne okolnosti u svezi s prijavljenim nesretnim slučajem. Kad osiguranik ne bi postupio prema odredbama ugovora te zbog takvog postupanja pridonio nastanku invaliditeta ili tome da invaliditet bude veći nego što bi inače bio, ima pravo samo na razmjerno smanjenu naknadu. ${ }^{59}$

\footnotetext{
57 Rječnik osiguranja, op. cit. u bilj. 77, str. 354.

58 Čl. 941. ZOO-a. 


\subsubsection{Utvrđivanje prava korisnika osiguranja-izvid, procjena i obračun štete, vještačenje}

Nakon urednog izvršenja obveze prijave nastale štete postupak naplate osigurnine prolazi kroz sljedeći pravni filter koji prethodi isplati osiguranog iznosa. Naredna faza utvrđivanja prava korisnika iz police osiguranja svodi se na ustanovljenje bitnih činjenica od kojih zavisi isplata osigurnine te volumen naknade, ovisno o tome kakvu je konkretnu posljedicu na zdravstvenu sferu osiguranika prouzročio nesretni događaja (smrt osiguranika, invaliditet, privremena nesposobnost). U ovoj fazi rješavanja štete stručna osoba osiguratelja - procjenitelj štete - mora izvršiti uvid u relevantnu dokumentaciju (štetovni spis) te organizirati izvid i procjenu štete. O rezultatima izvida štete izravno zavisi pravo korisnika osiguranja na isplatu osigurnine jer se navedenim postupkom utvrđuju kako uzrok nastanka osiguranog slučaja i posljedično ostvarenog rizika (štete), tako i opseg nastale štete. ${ }^{60}$

S ciljem utvrđenja prava korisnika iz analiziranog ugovora o osiguranju sportaša od nesretnog slučaja (nezgode), u slučaju kad je nesretni slučaj imao za posljedicu invaliditet, osiguranik je dužan podnijeti: prijavu, policu, dokaz o uplaćenoj premiji, dokaz o okolnostima nastanka nesretnog slučaja i medicinsku dokumentaciju s utvrđenim posljedicama radi određivanja konačnog postotka trajnog invaliditeta.

Procjena i obračun štete će se temeljiti na konačnom postotku invaliditeta kojeg određuje osiguratelj prema tablici za određivanje postotka trajnog invaliditeta kao posljedice nesretnog slučaja (nezgode). Provođenje postupka vještačenja predviđeno je za sve situacije kada ugovaratelj, osiguranik ili korisnik i osiguratelj nisu suglasni u pogledu vrste, uzroka ili posljedica nesretnog slučaja, kao i u pogledu visine obveze osiguratelja. Dakle, uvijek kada postoji spor glede pravnorelevantnih činjenica, utvrđivanje spornih činjenica povjerit će vještacima određene specijalizacije, a pri čemu jednog imenuje osiguratelj, a drugog suprotna strana. Nadvještačenje je ugovoreno za slučaj nesuglasja u nalazima imenovanih vještaka što se rješava tako da oni zajednički određuju trećeg vještaka, koji će dati svoje stručno mišljenje samo u pogledu onih činjenica koje su među njima sporne i u granicama njihovih nalaza i mišljenja.

\subsubsection{Isplata osiguranog iznosa - likvidacija štete}

Nakon što su stvorene pravne pretpostavke za isplatu osiguranog iznosa osiguratelj će isplatiti osigurani iznos odnosno njegov odgovarajući dio ili ugovorenu dnevnu naknadu osiguraniku odnosno korisniku u roku od 14 dana nakon što bude obveza osiguratelja i visina obveze utvrđena, sve pod uvjetom da je nesretni slučaj nastupio za vrijeme trajanja osiguranja i ako su posljedice nesretnog slučaja nastupile tijekom godine dana od dana nastanka nesretnog slučaja. Konačni postotak invaliditeta određuje se prema tablici invaliditeta poslije završenog liječenja u vrijeme kad je kod osiguranika u odnosu na ozljede i nastale posljedice nastupilo stanje ustaljenosti, tj. kada se prema liječničkom predviđanju ne može očekivati da

60 Stipić, M., op. cit. u bilj. 22, str. 125. 
će se stanje pogoršati ili poboljšati. ${ }^{61}$ Ako kao daljnja posljedica nesretnog slučaja nastupi smrt osiguranika ili invaliditet, osiguratelj isplaćuje korisniku, odnosno osiguraniku, iznos osiguranog iznosa predviđenog za takve slučajeve bez obzira na isplaćenu dnevnu naknadu za privremenu nesposobnost za rad ili isplaćenu naknadu troškova liječenja. ${ }^{62}$

\section{ZAKLJUČAK}

Osiguranje sportaša od sportskih ozljeda u okviru hrvatskog osigurateljnog tržišta još uvijek nije steklo status važnije teme pa su posljedično navedena osiguranja relativno rijetka u našoj praksi. Istodobno ponuđeni uvjeti osiguranja međusobno su podudarni u bitnim elementima bez značajnijih odstupanja što svjedoči

61 Ako to stanje ne nastupi ni po isteku treće godine od dana nastanka nesretnog slučaja, kao konačno stanje uzima se stanje po isteku toga roka i prema njemu se određuje postotak invaliditeta. Ako nije moguće poslije nastanka nesretnog slučaja utvrditi konačni postotak invaliditeta, osiguratelj će osiguraniku isplatiti iznos koji nesporno odgovara postotku invaliditeta za koji se već tada može na temelju medicinske dokumentacije utvrditi da će trajno ostati. Ako osiguranik umre prije isteka godine dana od dana nastanka nesretnog slučaja od posljedica toga nesretnog slučaja, a konačni postotak invaliditeta je bio već utvrđen, osiguratelj isplaćuje iznos koji je određen za slučaj smrti odnosno razliku između osiguranog iznosa za slučaj smrti i iznosa koji je bio prije toga isplaćen na ime invaliditeta, ukoliko takva razlika postoji. Ako konačni postotak invaliditeta nije bio utvrđen, a osiguranik umre zbog istog nesretnog slučaja, osiguratelj isplaćuje osigurani iznos određen za slučaj smrti, odnosno samo razliku između tog iznosa ili eventualno već isplaćenog dijela (akontacije), ali samo tada ako je osiguranik umro najkasnije u roku od 3 godine od dana nastanka nesretnog slučaja. Ako prije utvrđenja konačnog postotka invaliditeta u roku od 3 godine od dana nastanka nesretnog slučaja nastupi smrt osiguranika iz bilo kojeg drugog uzroka, visinu obveze osiguratelja iz osnova invaliditeta utvrđuje liječnik na temelju postojeće medicinske dokumentacije... Ako osigurani slučaj ima za posljedicu osiguranikovu privremenu nesposobnost za rad, a ugovorena je isplata dnevne naknade, osiguratelj isplaćuje osiguranu naknadu u ugovorenoj visini od dana označenog u polici, a ukoliko taj dan nije određen, od prvog dana koji slijedi danu kada je započeto liječenje kod liječnika ili zdravstvene ustanove, pa do posljednjeg dana privremene nesposobnosti za rad, odnosno dana smrti ili utvrđenog invaliditeta, ali najviše za 200 dana. Ako je privremena nesposobnost za rad produžena iz bilo kojih zdravstvenih razloga, osiguratelj je dužan isplatiti dnevnu naknadu samo za vrijeme trajanja bolovanja prouzročenog isključivo nesretnim slučajem, bez obzira da li je bilo puno bolovanje ili sa skraćenim radnim vremenom, ali i u tom slučaju najviše za 200 dana. Ako nesretni slučaj ima za posljedicu boravak osiguranika u bolnici radi liječenja, a ugovorena je dnevna naknada za liječenje u bolnici, osiguratelj isplaćuje ugovorenu naknadu od prvog do zadnjeg dana boravka u bolnici, odnosno do dana smrti ili utvrđenog invaliditeta u smislu odredbe stavka (3) ili (4) ovog članka, ali najviše do 365 dana. nesretni slučaj ima za posljedicu narušavanje zdravlja osiguranika koje zahtijeva liječničku pomoć, a ugovorena je i naknada troškova liječenja, osiguratelj isplaćuje osiguraniku, bez obzira na to da li ima ikakvih drugih posljedica, prema podnijetim dokazima naknadu svih stvarnih i nužnih troškova liječenja nastalih najduže tijekom godine dana od dana nastanka nesretnog slučaja, ali najviše do ugovorenog iznosa. U troškove liječenja iz prethodnog stavka spada i nabava umjetnih udova, ali samo ako je to potrebno prema ocjeni liječnika. Osiguratelj je u obvezi naknaditi samo onaj dio troškova liječenja koje je stvarno snosio sam osiguranik i to samo za liječenje u Republici Hrvatskoj za osobe koje imaju obvezno zdravstveno osiguranje. Za osobe koje nemaju obvezno zdravstveno osiguranje, a nisu posebno ugovorile i platile odgovarajuću premiju, osiguratelj priznaje 50\% nastalih troškova. Ne postoji obveza osiguratelja za isplatu naknade troškova liječenja u toplicama i sličnim zdravstvenim ustanovama, kao ni za lijekove izvan medicinskih ustanova...U slučaju nesretnog slučaja i spašavanja osiguranika helikopterom ili zrakoplovom, osiguratelj naknađuje samo nužne i dokazane troškove koji su nastali radi spašavanja života osiguranika na nepristupačnim mjestima ili radi pružanja nužne i hitne mediçinske pomoći. Troškovi za spašavanje u pravilu se isplaćuju osobi koja dokaže da je snosila te troškove. Čl. 14. Općih uvjeta Croatia osiguranja d.d.

${ }_{62}$ Čl. 14. Općih uvjeta Croatia osiguranja d.d. 
nezainteresiranosti osiguravajućih kuća da učine iskorak u smjeru veće tržišne kompetitivnosti. Vrlo je uobičajeno da se ugovor o osiguranju zaključi u režimu sponzorstva od strane osiguratelja pri čemu se, u pravilu, ugovara protučinidba u obliku marketinške promocije korporativnog identiteta tvrtke osiguratelja i slično. $\mathrm{Na}$ osnovi iznesenog se zaključuje kako praktična važnost osiguranja još uvijek nije dostatno prepoznata na hrvatskom tržištu. U prilog tome govori i činjenica da važeći Zakon o sportu ne dotiče problematiku osiguranja u sportu bez obzira na iznimnu aktualnost teme koja je, između ostalog, uvjetovana vrhunskim sportskim rezultatima koje hrvatski sport ostvaruje na svjetskoj razini.

Općepoznato je da obavljanje sportske djelatnosti nosi sa sobom signifikantne rizike u vidu narušenja zdravlja i posljedičnih imovinskih gubitaka iz čega je proizišla potreba interpolacije instituta ugovornog osiguranja tako nastalih šteta. Ultima ratio osiguranja od sportskih ozljeda predstavljen je u ideji popravljanja, odnosno, sanacije i umanjenja svih onih nepovoljnih financijskih učinaka koji su rezultanta ostvarenog rizika za vrijeme prakticiranja određene sportske aktivnosti. Pravni model koji omogućuje djelotvornu pravno-ekonomsku zaštitu sportaša kao potencijalnih oštećenika jest upravo ugovor o osiguranju sportaša od posljedica nesretnog slučaja. Naime, pravni odnos između osiguratelja, ugovaratelja osiguranja i osiguranika u suvremenom pravu se zasniva na ugovoru kojim se definiraju prava i obveze ugovornih strana u okviru osigurateljnog programa koncipiranog za osiguranje od nastupa nesretnog slučaja i ostvarenja osiguranog rizika per consequens. U hrvatskom pravu obveznopravni odnos između subjekata odnosnog ugovora o osiguranju redovito se zasniva na općim uvjetima koji generalno utvrđuju pravni okvir za osiguranje od nesretnog slučaja (nezgode), kao i na dopunskim uvjetima koji in specie definiraju posebne uvjete za osiguranje sportaša. Dakako, osnovni pravni obrazac ugovora o osiguranju sportaša od nesretnog slučaja determiniran je odredbama ZOO-a.

Provedena usporedna analiza opsega osigurateljnog pokrića u hrvatskoj osigurateljnoj ponudi, na osnovi dva referenta ugovora vodećih osiguratelja, ukazala je da se u pravnom smislu radi o praktično identičnom ugovornom konceptu u pogledu svih bitnih sastojaka ugovora, definicije pravno relevantnih pojmova, te u pogledu predmeta osiguranja, odnosno, osiguranih rizika. Pravne razlike se uočavaju tek u pogledu eventualnih dodatnih klauzula kojima se mogu ugovoriti posebna pokrića u vezi sa nastupom nesretnog slučaja, dok su značajnije varijacije u ugovorima ekonomske naravi i nisu bile predmetom ovog istraživanja.

Kod obveznopravnih poslova, kojima pripada i analizirani ugovor o osiguranju, pravni odnos će nastati samo ako su ispunjene sljedeće pretpostavke valjanosti pravnog posla: (1) sposobnost pravnog subjekta; (2) suglasno i valjano očitovanje volje; (3) mogućnost, dopuštenost, određenost ili barem odredivost sadržaja; (4) i oblik pravnog posla, ako je to posebno ugovoreno ili propisano kao u slučaju ugovora o osiguranju. Bitno je napomenuti da u hrvatskom pravu, ugovor o osiguranju sportaša od nesretnog slučaja neće biti pravno valjan i pored ispunjenja općih pravnih pretpostavki, ukoliko osigurani rizik s obzirom na posljedice koje može 
izazvati ne pripada kategoriji tzv. čistih rizika, a nikako kategoriji špekulativnih rizika. Dakle, posebnu pretpostavku valjanosti svakog govora o osiguranju čini zahtjev da predmetom osiguranja mogu biti samo pojedinačni čisti osigurljivi rizici, sukladno najdubljim pobudama ugovaratelja osiguranja. Posebno valja istaći da pitanje pravne kvalifikacije osigurljivog rizika, odnosno, determiniranje pravno relevantnog sadržaja pojma takvog rizika nije uvjetovano zakonskim odredbama već dugogodišnjom osigurateljnom praksom.

Nastavno je istražena pravna konstrukcija osiguranog slučaja u relaciji sa osiguranim rizikom. Tako u hrvatskom pravu osigurani slučaj predstavlja događaj prouzročen osiguranim rizikom. Njegova osnovna karakteristika jest da se zasniva na objektivnoj činjenici koja je nastala u budućnosti i u neizvjesnim okolnostima, te izvan volje sukontrahenata ugovora o osiguranju. U pogledu osiguranog rizika hrvatsko pozitivno pravo propisuje njegova bitna obilježja te određuje da mora biti budući, neizvjestan i nezavisan od isključive volje ugovaratelja osiguranja ili osiguranika. Kad je u pitanju strukturna funkcionalna međuzavisnost slučaja i rizika sa svojim pravostvarajućim učinkom, istraživanje je ukazalo da u osnovi pravnog konstrukta osiguranog slučaja (nesretni slučaj) stoji sasvim određena, konkretna i faktična situacija koja je u kauzalnom odnosu sa osiguranim rizikom koji uvijek opstoji kao hipotetička kategorija s obilježjem asertivnosti, budući da svoje postojanje in abstracto ne duguje drugom uzroku. To stoga što osigurani rizik uvijek opstoji kao mogućnost, dok se osigurani slučaj tek treba dogoditi. Naime, svaki događaj koji predstavlja nesretni slučaj in rerum natura, iako možda odgovara pojmovnoj definiciji iz ugovora o osiguranju, nema per se obilježje osiguranog slučaja. Drugim riječima, očekuje se nastup takvog nesretnog slučaja koji će in concreto uzrokovati određeni osigurani rizik sukladno ugovoru osiguranju, a čime odnosni nesretni događaj izvorno stječe svojstvo osiguranog slučaja.

\section{AN ATHLETE'S INSURANCE CONTRACT IN ACCIDENT CASE}

Sports activities carry with significant risk in terms of negatively affecting health and consequentially financial loss from which arose the need for an interpolation of the institute of contractual insurance with respect to the onset of such consequential damages. The legal model providing effective protection of financial interests for sportspersons as potential injured parties is actually a contracted policy to insure the sportsperson against the consequences of an accident which has been chosen as the main research issue in this paper. The appropriate application of scientific methods has determined the relevant tort civil law framework for providing the insuree's legal protection against sports injuries within Croatian law with an overview of the particular presumptions in concluding a typical insurance policy - the existence of the insuree's risks as legal and factual issues sui generis.

key words: sports insurance, accident insurance contract, secured case, insured risk, accident cases, sports bodily injury, insurance law, civil law 